\title{
Evaluation of a Polymerase Chain Reaction for the Diagnosis of Leptospirosis in Cattle
}

\author{
María Inés Baquero, Nadia López, María Eugenia Mejía and Gabriel Trueba* \\ Instituto de Microbiología, Universidad San Francisco de Quito, Vía Interoceánica y Diego de Robles, Círculo \\ Cumbayá, Quito, Ecuador
}

\begin{abstract}
Bovine leptospirosis is a highly prevalent infection worldwide causing serious losses in cattle production and serving as a source for human infection. Diagnosis and assessment of prevalence of this infection in bovine herds is difficult due to limitations of current procedures. The present report describes the adaptation of a polymerase chain reaction (PCR) protocol for detection of leptospiral DNA in bovine urine. The amplification products corresponded to a segment of the Leptospira 16S rRNA gene detected using two sets of primers (A/B and C/D). A total of 547 urine samples from Bos taurus $(\mathrm{n}=327)$ and Bos indicus $(\mathrm{n}=220)$ were collected from animals in Andean and Coastal regions of Ecuador, either by furosemide-induced urination or from bladders at the slaughterhouse. The results of this research showed a PCR positivity of $13.52 \%$ using primers A/B. Bos taurus samples obtained by urination and those obtained from bladder showed a significant difference in PCR positivity $(P=0.036)$. Differentiation of Leptospira species was preformed by DNA sequencing of the amplified products. Three amplicons showed 90 and $98 \%$ sequence identity with $L$. borgpetersenii and $98 \%$ identity with $L$. inadai. The results of this study suggest that PCR could be an excellent approach for epidemiological studies.
\end{abstract}

Keywords: Leptospirosis, diagnosis, PCR, 16S rRNA, Lesptospira borgpetersenii, Bos taurus, Bos indicus.

\section{INTRODUCTION}

Leptospirosis is a zoonotic worldwide disease caused by pathogenic species of the genus Leptospira [1]. In cattle this infection causes infertility, abortion, stillbirths, reduced milk production, and even death [2]. Leptospira interrogans serovar Hardjo type Hardjo-bovis is the primary cause of acute and chronic leptospirosis in cattle, in addition causes persistent infection of kidneys and female reproductive tract [3]. Contact with urine is probably the most common transmission route [3]. Human infections among dairy farmers are common where the disease is known as milker's fever [4].

Leptospiral isolation is costly, very difficult, and often unsuccessful $[5,6]$. The standard laboratory diagnosis of bovine leptospirosis is performed using the microscopic agglutination test (MAT); this technique is time consuming, cumbersome, and requires trained personnel $[6,7]$. Serologic tests do not allow early leptospiral diagnosis, especially in infections caused by serovar Hardjo type Hardjo-bovis $[2,8]$. Although MAT provides some information about infecting serovars, cross-reactivity among serovars is of concern [2]. MAT also is unable to differentiate between natural infection and vaccine induced titres $[2,9]$. In addition a false negative assay may result from the absence of specific serovars in the assay.

*Address correspondence to this author at the Instituto de Microbiología, Universidad San Francisco de Quito, Vía Interoceánica y Diego de Robles, Círculo Cumbayá, Quito, Ecuador; Tel: 59322890070; Fax: 59322971836; E-mail: gtrueba@usfa.edu.ec
It is necessary to improve diagnostic procedures for animal leptospirosis. Molecular techniques such as PCR have the potential to improve leptospirosis diagnosis [10, 11]. The aim of this research was to evaluate a PCR protocol for the investigation of leptospirosis infection in cattle from dairy farms and at slaughterhouses. A PCR protocol which amplifies a segment of the leptospiral 16S rRNA gene [12] was chosen for evaluation and to also allow the possibility of detecting infecting species.

\section{MATERIALS AND METHODOLOGY}

\section{Urine Samples from Cattle}

Four field veterinarians were instructed to collect urine samples (from asymptomatic animals) using diuretic furosemide as previously described [13]. A total of 269 Bos taurus urine samples from 29 farms close to Quito (Andean region) were collected in sterile tubes. Additionally, bladder urine samples from Bos taurus $(\mathrm{n}=58)$ and Bos indicus $(n=220)$ were collected at the local slaughterhouse by cystocentesis. Species identification of the cattle was based on phenotypic features. Bos taurus samples came from Andean farms whereas $B$. indicus came from the Coastal region (tropical). Information about the origin of the animals was obtained from slaughterhouse personnel.

\section{DNA Extraction}

A modification of a previously published protocol was used [14]. Urine samples (approximately $50 \mathrm{ml}$ ) were transported to the laboratory on ice and immediately centrifuged at $3,287 \mathrm{X} g$ for 15 minutes; the pellet was resuspended in $1 \mathrm{ml}$ of $1 \mathrm{X}$ PBS [137 mM NaCl, $2.7 \mathrm{mM}$ 
$\mathrm{KCl}, 4.3 \mathrm{mM} \mathrm{Na} 2 \mathrm{HPO}_{4}, \mathrm{H}_{2} \mathrm{O}, 1.4 \mathrm{mM} \mathrm{K \textrm {K } _ { 2 }} \mathrm{PO}_{4},(\mathrm{pH}$ 7)] transferred to a $1.5 \mathrm{ml}$ tube and centrifuged for 5 minutes at $9,660 \mathrm{X} g$; followed by a second wash of the pellet preformed with $1 \mathrm{ml}$ of $1 \mathrm{X}$ PBS. After removal of the supernatant, $700 \mu 1$ of a solution containing $2 \%$ CTAB, [1.4 $\mathrm{mM} \mathrm{NaCl}, 20 \mathrm{mM}$ EDTA, $100 \mathrm{mM} \mathrm{HCl}(\mathrm{pH} 8)$ ] was added to each sample and incubated at $65^{\circ} \mathrm{C}$ for 2 hours with vortexing every 15 minutes. Samples were cooled to room temperature and $700 \mu \mathrm{l}$ of Chloroform/isoamyl alcohol (24:1) were added, homogenized, and centrifuged at 9,660 X $g$ for 5 minutes; the supernatants were transferred to a new sterile tube, $50 \mu 1$ of sodium acetate and $1000 \mu 1$ of $100 \%$ ethanol were added and stored at $-20^{\circ} \mathrm{C}$ overnight for DNA precipitation. Samples were centrifuged at $13,148 \mathrm{X} g$ for 10 minutes, and supernatants were removed, pellets were washed with $1 \mathrm{ml}$ of ethanol $75 \%$ and centrifuged for 10 minutes at $13,148 \times g$. The supernatants were discarded and pellets were allowed to dry at room temperature for approximately 15 minutes, and finally resuspended in 25 or $50 \mu 1$ of TE buffer and stored at $-20^{\circ} \mathrm{C}$ until used.

\section{Urine Experimentally Mixed with Leptospira}

In order to test the level of detection and the presence of PCR inhibitors, a log phase culture of Leptospira interrogans serovar Saxkoebing in EMJH medium (Leptopira Medium Ellinghausen-McCullough/ JohnsonHarris) [15] $\left(1.52 \times 10^{8}\right.$ cells $/ \mathrm{ml}$ as determined by PetroffHausser Chamber count) was subjected to 810 -fold dilutions in urine from a PCR negative cow. The DNA was extracted from $1 \mathrm{ml}$ of each dilution as described previously, the final DNA pellet was re-suspended in $25 \mu 1$ of TE buffer and $2.5 \mu 1$ of the re-suspended pellet were used in each PCR reaction.

\section{PCR Assay}

The PCR protocol used in this paper was previously described [12]. Primers A/B (Fig. 1) allowed the amplification of a $331 \mathrm{bp}$ fragment of the leptospiral $16 \mathrm{~S}$ rRNA gene. An internal set of pimers C/D (Fig. 1) were used for PCR confirmation. The PCR assay conducted, consisted of 40 cycles: denaturation at $94{ }^{\circ} \mathrm{C}$ for 3 minutes, annealing at $63^{\circ} \mathrm{C}$ for 1.2 minutes, and elongation at $72^{\circ} \mathrm{C}$ for 30 seconds. PCR products were analyzed by electrophoresis in $1.2 \%$ agarose gels. Each PCR reaction was run with positive (DNA from L. interrogans culture) and negative control (no DNA template).

An analysis of the primer sequences was performed in order to identify potential mismatch problems; nucleotide sequences of all primers were compared to homologous leptospiral sequences in GenBank using BLAST (blastn) (www.ncbi.nlm.nih.gov/blast/Blast.cgi).

\section{Positive Samples DNA Sequencing}

Nine amplicons were sent to Macrogen (Seoul, South Korea) for DNA sequencing. Amplicons corresponded to both set of primers (A/B and C/D). Sequences were compared to those in GenBank using BLAST. Phylogenetic analysis was carried out using Mega 4.1 package.

\section{Statistical Analysis}

Correlation Contingency analysis was performed and significance checked with Fisher's exact test (two-tailed test). P-value $<0.05$ were considered significant.

\section{RESULTS}

\section{PCR Amplification}

Amplification of DNA extracted from artificially contaminated urine samples indicated that PCR using primers $\mathrm{A} / \mathrm{B}$ and $\mathrm{C} / \mathrm{D}$ was able to detect spirochetes even in a $10^{9}$ fold dilution suggesting that DNA extracts from urine did not contain any inhibitory compound. Polymerase chain reaction analysis using primers $\mathrm{A} / \mathrm{B}$ of 547 urine samples showed $13.52 \%$ positivity. There was a significant difference of positivity $(P=0.036)$ between Bos taurus samples obtained by urination $(22.3 \%)$ and those obtained directly from the bladder (8.6\%). No significant difference in positivity existed between Bos taurus bladder $(8.6 \%)$ and Bos indicus bladder samples $(4.1 \%)(P=0,321)$ (Table 1).

Table 1. Leptospirosis Positivity Using PCR Primers A/B in Cattle Urine

\begin{tabular}{|c|c|c|c|}
\hline \multirow{2}{*}{} & \multicolumn{3}{|c|}{ Bovine Species and Type of Sample } \\
\cline { 2 - 4 } & $\begin{array}{c}\text { B. indicus } \\
\text { Bladder }\end{array}$ & $\begin{array}{c}\text { B. taurus } \\
\text { Bladder }\end{array}$ & $\begin{array}{c}\text { B. taurus } \\
\text { Urination }\end{array}$ \\
\hline \hline Number of samples & 220 & 58 & 269 \\
\hline Number positive samples & 9 & 5 & 60 \\
\hline Percentage of positivity & 4.1 & 8.6 & 22.3 \\
\hline
\end{tabular}

Urine samples were obtained either by induced urination from cattle in farms located close to Quito or from bladders at the local slaughterhouse.

\section{Performance of Primers A/B and C/D}

Primers $\mathrm{C} / \mathrm{D}$ were originally designed to confirm leptospiral origin of PCR products [12] (the product of C/D is internal to the amplicon obtained with $\mathrm{A} / \mathrm{B}$ ), however we found that some samples that were negative to primers $\mathrm{A} / \mathrm{B}$ were positive for primers $\mathrm{C} / \mathrm{D}$. Therefore, a subset of 58 urine samples collected from bladder was used to compare sensitivity of both set of primers (Table 2). Five samples (corresponding to $8.6 \%$ of the total number of samples) were positive when primers $\mathrm{A} / \mathrm{B}$ were used, however this value increased to $9(15.51 \%$ of the total number of samples) when primers $\mathrm{C} / \mathrm{D}$ were used $(P=0.508)$, however the same 5 samples that were positive with primers $\mathrm{A} / \mathrm{B}$ were also positive when primers $\mathrm{C} / \mathrm{D}$ were used. Additionally $57 \mathrm{~B}$. taurus urination samples previously tested for $\mathrm{A} / \mathrm{B}$ primers PCR, were also tested for primers C/D (Table 2); 32 of 57 $(56.14 \%)$ DNA samples which were positive to PCR with $\mathrm{A} / \mathrm{B}$ primers were also positive with $\mathrm{C} / \mathrm{D}$ primers. In order to investigate the discrepancies of PCR reactions using the two set of primers, primer sequences were compared to the leptospiral homologous sequences deposited in the GenBank. Primer A was found to have some mismatches with sequence of L. meyeri Ranarum [GenBank:Z21648]; primer B had mismatches with sequences of: L. inadai serovar Lyme 10 ATCC [GenBank: AY631896], L. fainei Hurstbridge 1 [GenBank:AY995712], L. meyeri serovar Semaranga Veldrat [GenBank:FJ154599] and L. inadai serovar Aguaruna [GenBank:AY631891]; primer C had mismatches with corresponding sequences of: $L$. inadai serovar Lyme 10 ATCC [GenBank: AY631896], L. fainei Hurstbridge [GenBank:AY995712], L. meyeri RANARUM 
a) Primer A:

\section{Primer A}

Leptospira inadai (Lyme) [GenBank:AY631896]

Leptospira fainei [GenBank: AY995712]

Leptospira borgpetersenii [GenBank: FJ154586]

Leptospira santarosai [GenBank:FJ154589]

Leptospira kirschneri [GenBank:DQ991477]

Leptospira weilii [GenBank:U12677]

Leptospira Noguchi [GenBank:AY631886]

L. meyeri (Ranarum) [GenBank:Z21648]

Leptospira interrogans [GenBank: FJ812169]

Leptospira meyeri (Semaranga) [GenBank:FJ154599]

Leptospira inadai (Aguaruna) [GenBank:AY631891] $5^{\prime}$

$\begin{array}{llllllllllllllllllll}\mathbf{G} & \mathbf{G} & \mathbf{C} & \mathbf{G} & \mathbf{G} & \mathbf{C} & \mathbf{G} & \mathbf{C} & \mathbf{G} & \mathbf{T} & \mathbf{C} & \mathbf{T} & \mathbf{T} & \mathbf{A} & \mathbf{A} & \mathbf{A} & \mathbf{C} & \mathbf{A} & \mathbf{T} & \mathbf{G}\end{array}$ b) Primer B

\section{Primer B}

Leptospira inadai (Lyme) [GenBank:AY631896]

Leptospira fainei [GenBank: AY995712]

Leptospira borgpetersenii [GenBank: FJ154586]

Leptospira santarosai [GenBank:FJ154589]

Leptospira kirschneri [GenBank:DQ991477]

Leptospira weilii [GenBank:U12677]

Leptospira Noguchi [GenBank:AY631886]

L. meyeri (Ranarum) [GenBank:Z21648]

Leptospira interrogans [GenBank: FJ812169]

Leptospira meyeri (Semaranga) [GenBank:FJ154599]

Leptospira inadai (Aguaruna) [GenBank:AY631891] $3^{\prime}$

$\begin{array}{lllllllllllllllllllll}\mathbf{A} & \mathbf{A} & \mathbf{T} & \mathbf{C} & \mathbf{T} & \mathbf{T} & \mathbf{G} & \mathbf{C} & \mathbf{T} & \mathbf{C} & \mathbf{A} & \mathbf{A} & \mathbf{T} & \mathbf{G} & \mathbf{G} & \mathbf{G} & \mathbf{G} & \mathbf{G} & \mathbf{G} & \mathbf{A} & \mathbf{A}\end{array}$

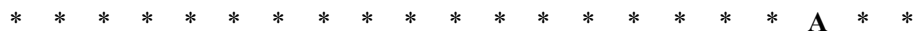

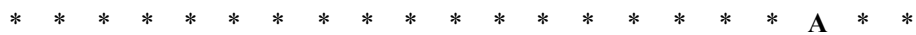

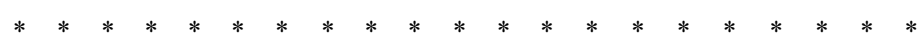

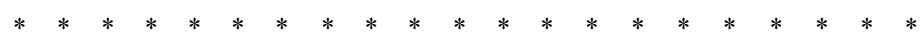

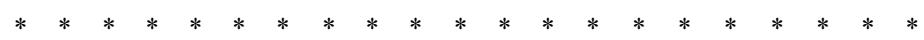

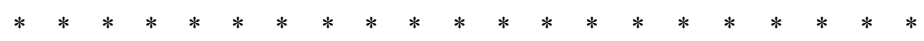

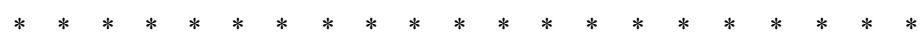

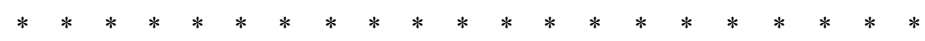

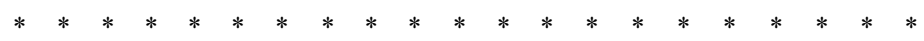

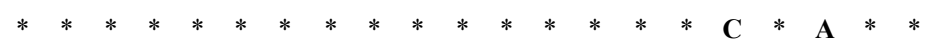

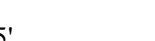

c) Primer $\mathrm{C}$

\section{Primer C}

Leptospira inadai (Lyme) [GenBank:AY631896]

Leptospira fainei [GenBank: AY995712]

Leptospira borgpetersenii [GenBank: FJ154586]

Leptospira santarosai [GenBank:FJ154589]

Leptospira kirschneri [GenBank:DQ991477]

Leptospira weilii [GenBank:U12677]

Leptospira Noguchi [GenBank:AY631886]

L. meyeri (Ranarum) [GenBank:Z21648]

Leptospira interrogans [GenBank: FJ812169]

Leptospira meyeri (Semaranga) [GenBank:FJ154599]

Leptospira inadai (Aguaruna) [GenBank:AY631891]

d) Primer D

\section{Primer D}

Leptospira inadai (Lyme) [GenBank:AY631896]

Leptospira fainei [GenBank: AY995712]

Leptospira borgpetersenii [GenBank: FJ154586]

Leptospira santarosai [GenBank:FJ154589]

Leptospira kirschneri [GenBank:DQ991477]

Leptospira weilii [GenBank:U12677]

Leptospira Noguchi [GenBank:AY631886]

L. meyeri (Ranarum) [GenBank:Z21648]

Leptospira interrogans [GenBank: FJ812169]

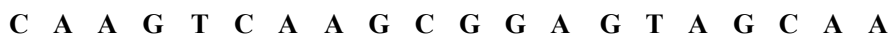

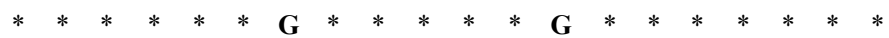

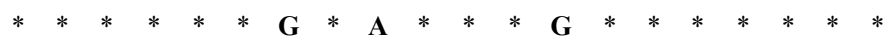

$* \begin{array}{lllllllllllllllllll}* & * & * & * & * & * & * & * & * & * & * & * & * & * & * & * & * & * & *\end{array}$

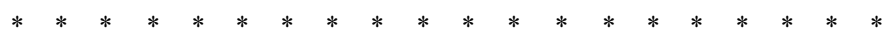

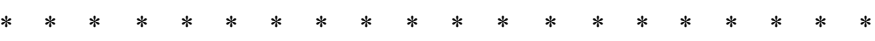

$* \begin{array}{lllllllllllllllllll}* & * & * & * & * & * & * & * & * & * & * & * & * & * & * & * & * & * & *\end{array}$

$\begin{array}{llllllllllllllllllll}* & * & * & * & * & * & * & * & * & * & * & * & * & * & * & * & * & * & * & *\end{array}$

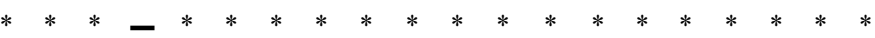

$* \begin{array}{lllllllllllllllllll}* & * & * & * & * & * & * & * & * & * & * & * & * & * & * & * & * & * & *\end{array}$

$\begin{array}{llllllllllllllllll}* & * & * & * & * & * & * & \mathbf{A} & * & * & * & \mathbf{C} & * & * & * & * & * & *\end{array}$

$\begin{array}{lllllllllllllllllll}* & * & * & * & * & \mathbf{G} & * & * & * & * & * & \mathbf{G} & * & * & * & * & * & * & *\end{array}$

3'

$5^{\prime}$

$\begin{array}{llllllllllllllllllll}\mathbf{T} & \mathbf{A} & \mathbf{C} & \mathbf{G} & \mathbf{G} & \mathbf{G} & \mathbf{A} & \mathbf{G} & \mathbf{G} & \mathbf{C} & \mathbf{A} & \mathbf{G} & \mathbf{C} & \mathbf{A} & \mathbf{G} & \mathbf{T} & \mathbf{T} & \mathbf{A} & \mathbf{A} & \mathbf{G}\end{array}$

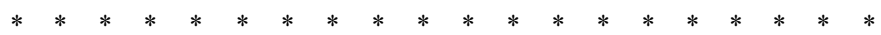

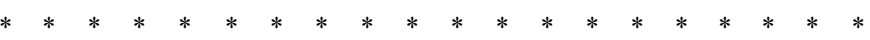

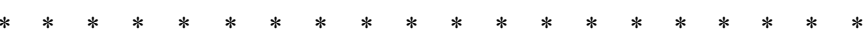

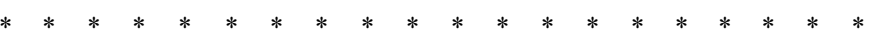

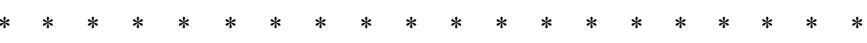

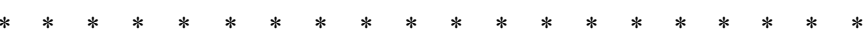

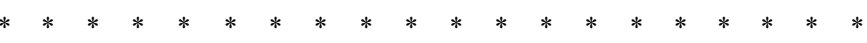

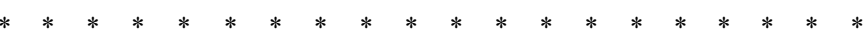

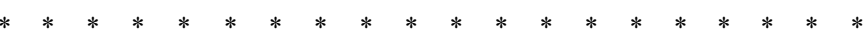

Leptospira meyeri (Semaranga) [GenBank:FJ154599] $\quad * \quad * \quad * \quad * \quad * \quad * \quad * \quad * \quad * \quad * \quad * \quad * \quad * \quad * \quad * \quad * \quad * \quad * \quad * \quad *$

Leptospira inadai (Aguaruna) [GenBank:AY631891] $\quad * \quad * \quad * \quad * \quad * \quad * \quad * \quad * \quad * \quad * \quad * \quad * \quad * \quad * \quad * \quad * \quad * \quad * \quad * \quad *$

Fig. (1). Mismatches found between primer sequences and leptospiral 16S rRNA gene sequences found in GenBank. Asterisk indicate nucleotide identity and horizontal line indicate gap. DNA sequences of leptospiral species and their respective accession numbers are indicated. 
[GenBank:Z21648], L. meyeri serovar Semaranga Veldrat [GenBank:FJ154599] and L. inadai serovar Aguaruna [GenBank:AY631891]; there were no mismatches found with primer D (Fig. 1).

Table 2. Performance of Primers $A / B$, and C/D

\begin{tabular}{|c|c|c|c|c|}
\hline $\begin{array}{c}\text { Type of } \\
\text { Sample }\end{array}$ & $\begin{array}{c}\text { Number of } \\
\text { Samples }\end{array}$ & $\begin{array}{c}\text { Positive } \\
\text { A/B }\end{array}$ & $\begin{array}{c}\text { Positive } \\
\text { C/D }\end{array}$ & $\begin{array}{c}\text { Positive } \\
\text { A/B, C/D }\end{array}$ \\
\hline \hline Bladder & 58 & 5 & 9 & 5 \\
\hline Urination & 57 & 57 & 32 & 32 \\
\hline Total & 115 & 62 & 41 & 37 \\
\hline
\end{tabular}

A subset of 58 urine samples collected from Bos taurus at the slaughterhouse in Quito, as well as 57 urination samples from Bos taurus dairy cattle, that were tested with the two sets of primers.

\section{DNA Sequencing}

Readable sequences were retrieved from 4 amplicons out of 9 , three of which showed $90-98 \%$ homology to $L$. borgpetersenii and one $98 \%$ to L. inadai (Fig. 2).

\section{DISCUSSION}

This report demonstrates that a previously described PCR protocol could be successfully used in diagnosis of bovine leptospirosis. Additionally, the amplification of $16 \mathrm{~S}$ rRNA gene allowed the identification of infecting leptospiral species. Other reports describing results of PCR application in urine using a different set of primers and a DNA extraction kit for urine found 35\% positivity in cattle in USA [16]. In the present manuscript a $22.3 \%$ positivity was found in similar samples (Bos taurus induced urination) in dairy cattle. The prevalence of leptospirosis in cattle is often investigated by use of the microscopic agglutination test (MAT) [6, 7, 17]. MAT yields limited information about infecting serovars [6]. Even though nucleotide data do not supply evidence of infecting serovars [1, 2], amplicons containing 16S rRNA gene sequences allow the identification of the infecting species. In the present study three nucleotide sequences showed high sequence homology to L. borgpetersenii ribosomal genes suggesting infection by serovar Hardjo type Hardjo-bovis, the most common Leptospira found in cattle around the world $[18,19]$. It is likely that the advent of new generation sequencing procedures will produce inexpensive high quality sequence very useful for epidemiological studies. The16S rRNA sequences are conserved among members of leptospiral species therefore this approach may allow to recognize the infecting specie but may not be able to identify clonal relationships.

The protocols presented here for DNA extraction are inexpensive, do not leave any inhibitory residue in the sample and produce stable DNA extracts, this procedure has been used previously for the detection of Leptospira in urine samples [20]. Urine samples from induced urination showed a significant higher positive results $(P=0.036)$ than samples obtained directly from bladder. It is possible that urine from induced urination may contain a larger number of spirochetes due to carryover from female genital tract, which is often colonized by Leptospira $[2,21]$. Also the used of diuretic might actually enhance the flushing of spirochetes into the urine, whereas static urine in the bovine bladder may lead to death of the spirochetes and potential breakdown of DNA. However, urine samples from induced urination were not collected randomly so it is likely that chosen animals were showing some signs of leptospirosis. A higher number of positive samples (from bladder) were observed in samples form $B$. taurus than $B$. indicus even though it was not statistically significant. These observations may require additional research because B. taurus and Bos indicus are raised in different environments, highlands and lowlands respectively.

The discrepancy in reactivity observed in PCR using primers $\mathrm{A} / \mathrm{B}$ and $\mathrm{C} / \mathrm{D}$ might be partially explained by mismatches of the primers with DNA sequences from leptospiras in the field, however many of these mismatches found seemed to be located in non-critical regions [22, 23]. Based on the results presented here, it is advisable to use both sets of primers in order to capture all positive samples.

\section{ACKNOWLEDGEMENTS}

We thank Fernando Salas and Manuel Wong for urine sample collection, to Verónica Barragán and Juan Carlos Escobar for their technical advice, David Alt for his useful comments and Daisy Parrales for her assistance in the laboratory.

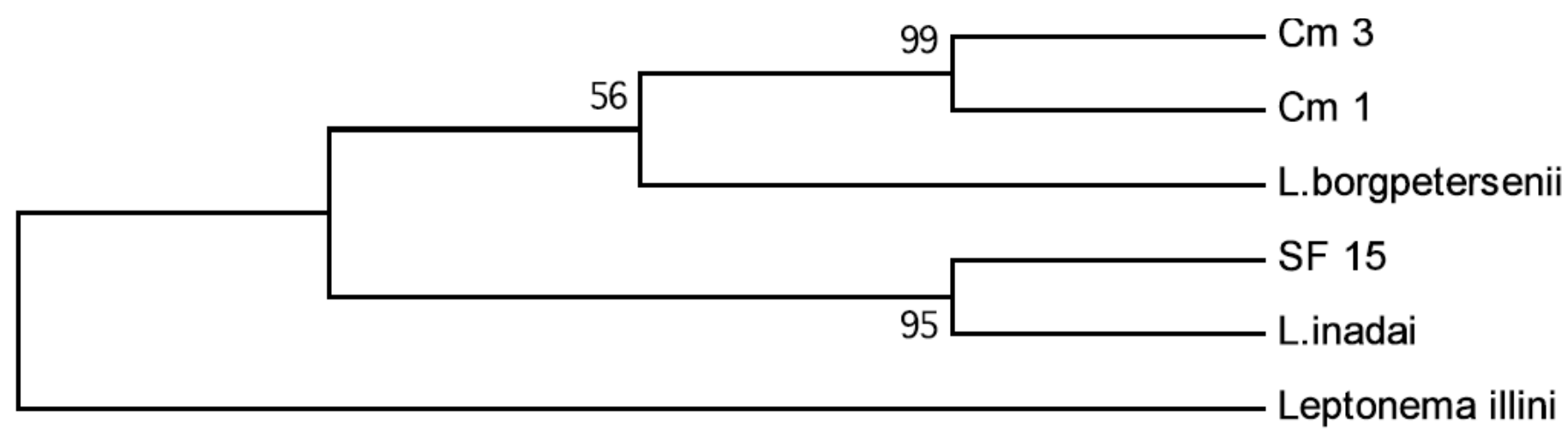

Fig. (2). Phylogenetic analysis of DNA sequences of three amplicons obtained from cattle urine. Amplicons were sequenced and DNA sequences were subjected to Maximum Parsimony analysis, numbers correspond to bootstrap values. Sequences obtained from urine samples are Cm 1 (submission number 1374057), Cm 3 (submission number 1374049), and SF 15 (submission number 1374060). Sequences of $L$. borgpetersenii [GenBank:FJ154600], L. inadai [GenBank:AY631896], and Leptonema illini [GenBank:AY714984]. 


\section{ABBREVIATIONS}

$$
\begin{array}{ll}
\mathrm{PCR} & =\text { Polymerase Chain Reaction } \\
\mathrm{DNA} & =\text { Deoxyribonucleic acid } \\
\mathrm{PBS} & =\text { Phosphate-buffer saline } \\
\mathrm{CTAB} & =\text { Cetyl trimethylammonium bromide } \\
\mathrm{EDTA} & =\text { Ethylenediaminetetraacetic acid } \\
\mathrm{TE} & =\text { Tris- EDTA buffer } \\
\mathrm{EMJH} & =\text { Ellinghausen-McCullough-Johnson-Harris } \\
& \text { medium }
\end{array}
$$

\section{REFERENCES}

[1] Levett PN. Leptospirosis. Clin Microbiol Rev 2001; 14: 296-326.

[2] Bolin CA. Diagnosis and control of bovine leptospirosis. Proceedings of the 6th Western Dairy Management Conference. Reno Nevada 2003; pp. 155-60.

[3] Morey RE, Galloway RL, Bragg SL, Steigerwalt AG, Mayer LW, Levett PN. Species-specific identification of Leptospiraceae by 16S rRNA gene sequencing. J Clin Microbiol 2006; 44: 3510-16.

[4] Huitema SW, Pal TM, Groothoff JW. Milker's fever, an occupational disease on the increase. Ned Tijdschr Geneeskd 1989; 133: $1939-41$.

[5] Fearnley C, Wakeley PR, Gallego-Beltran J, et al. The development of a real-time PCR to detect pathogenic Leptospira species in kidney tissue. Res Vet Sci 2008; 85: 8-16.

[6] Luchessi PM, Arroyo GH, Etcheverría A, Parma AE, Seijo AC. Recommendations for the detection of Leptospira in urine by PCR. Rev Soc Bras Med Trop 2004; 37: 131-4.

[7] Bomfim MRQ, Koury CM. Evaluation of LSSP-PCR for identification of Leptospira spp. in urine samples of cattle with clinical suspicion of leptospirosis. Vet Microbiol 2006; 118: 27888.

[8] Gravekamp C, Van De Kemp H, Franzen M, et al. Detection of seven species of pathogenic leptospires by PCR using two sets of primers. J Gen Microbiol 1993; 139: 1691-700.

[9] Bomfim MRQ, Barbosa-Stancioli EF, Koury MC. Detection of pathogenic leptospires in urine from naturally infected cattle by nested PCR. Vet J 2008; 178: 251-56.

[10] Mérien F, Portnoi D, Bourhy P, Charavay F, Berlioz-Arthaud A, Baranton G. A rapid and quantitative method for the detection of Leptospira species in human leptospirosis. FEMS Microbiol Lett 2005; 249: 139-47.
[11] Kositanont U, Rugsasuk S, Leelaporn A, Phulsuksombati D, Tantitanawat S, Naigowit P. Detection and differentiation between pathogenic and saprophytic Leptospira spp. by multiplex polymerase chain reaction. Diagn Microbiol Infect Dis 2007; 57: $117-22$.

[12] Mérien F, Amouriaux P, Perolat P, Baranton G, Saint Girons I. Polymerase chain reaction for detection of Leptospira spp. in clinical samples. J Clin Microbiol 1992; 30: 2219-24.

[13] Gerritsen MJ, Olyhoek T, Smits MA, Bokhout BA. Sample preparation method for polymerase chain reaction-based semiquantitative detection of Leptospira interrogans serovar hardjo subtype hardjobovis in bovine urine. J Clin Microbiol 1991; 12: 2805-8.

[14] Ausubel Frederick M, Brent Roger, Kingston Robert E, et al. Current Protocols in Molecular Biology. USA: John Wiley \& Sons 2003.

[15] Johnson RC, Harris VG. Differentiation of pathogenic and saprophytic leptospires. I. Growth at low temperatures. J Bacteriol 1967; 94: 27-31

[16] Talpada MD, Garvey N, Sprowls R, Eugster AK, Vinetz JM. Prevalence of leptospiral infection in Texas cattle: implications for transmission to humans. Vector Borne Zoonotic Dis 2003; 3: 14147.

[17] Alonso-Andicoberry C, García-Peña FJ, Pereira-Bueno J, Costas E, Ortega-Mora LM. Herd-level risk factors associated with Leptospira spp. seroprevalence in dairy and beef cattle in Spain. Prev Vet Med 2001; 52: 109-17.

[18] Taylor MJ, Ellis WA, Montgomery JM, Yan KT, McDowell SW, Mackie DP. Magnetic immuno capture PCR assay (MIPA): detection of Leptospira borgpetersenii serovar hardjo. Vet Microbiol 1997; 56: 135-45.

[19] Yan KT, Ellis WA, Montgomery JM, Taylor MJ, Mackie DP McDowell SW. Development of an immunomagnetic antigen capture system for detecting leptospires in bovine urine. Res Vet Sci 1998; 64: 119-24.

[20] Masri SA, Nguyen PT, Gale SP, Howard CJ, Jung SC. A polymerase chain reaction assay for the detection of Leptospira spp. in bovine semen. Can J Vet Res 1997; 61: 15-20.

[21] Ellis WA, McParland PJ, Bryson DG, Thiermann AB, Montgomery J. Isolation of leptospires from the genital tract and kidneys of aborted sows. Vet Rec 1986; 118: 294-5.

[22] Ayyadevara S, Thaden JJ, Shmookler RJ. Discrimination of primer 39-nucleotide mismatch by taq DNA polymerase during polymerase chain reaction. Anal Biochem 2000; 284: 11-8.

[23] Bru D, Martin-Laurent F, Philippot L. Quantification of the detrimental effect of a single primer-template mismatch by realtime PCR using the 16S rRNA gene as an example. Appl Environ Microbiol 2008; 74: 1660-3.

(C) Baquero et al.; Licensee Bentham Open.

This is an open access article licensed under the terms of the Creative Commons Attribution Non-Commercial License (http://creativecommons.org/licenses/by-nc/ 3.0/) which permits unrestricted, non-commercial use, distribution and reproduction in any medium, provided the work is properly cited. 